\title{
Proposing an Extension of the Technology Acceptance Model to Explain Facebook User Acceptance of Facebook Event Page
}

\author{
Tran Thi Kim Phuong ${ }^{1} \&$ Tran Trung Vinh ${ }^{1}$ \\ ${ }^{1}$ University of Economics, The University of Danang, Danang City, Vietnam \\ Correspondence: Tran Thi Kim Phuong, University of Economics, The University of Danang, Danang City, \\ Vietnam. E-mail: phuong.ttk@due.edu.vn
}

Received: March 31, 2017

doi:10.5539/ass.v13n6p133
Accepted: May 3, $2017 \quad$ Online Published: May 31, 2017

URL: https://doi.org/10.5539/ass.v13n6p133

\begin{abstract}
The emergence and growth of social media today has changed the way that people communicate and interact with each other. Thus, social media has considered as an effective tool in the marketing campaign. In regard to event marketing, event planners and organizers use social media (e.g. social network sites) as an important marketing medium to increase the number of potential attendees to visit the events. However, the major challenge to event marketers is to fully understand the process of how social media marketing gain special event customers' acceptance. This study chose Facebook event page as study context and applied the technology acceptance model (TAM) as theoretical foundation. In addition, this paper synthesizes the theoretical basis of the event marketing, emotional factors, perceived relevance and its application to social media (e.g., Facebook event page) from previous studies. The study aims to come out with a conceptual model (extended TAM) which explains fully inner-mechanism of the relationships among variables: (1) the emotions that online fansexpress on Facebook affect their acceptance of the Facebook event page as a legitimate marketing tool; (2) perceived relevance from user perspective influence their acceptance of the Facebook event page; (3) this "acceptance" mechanism has an impact on fans' intentions to attend the event.
\end{abstract}

Keywords: Event marketing, Facebook event pages, technology acceptance model, arousal, valence, perceived relevance

\section{Introduction}

Social media today has a profound effect on the way that people communicate with each other. In particular, various forms of social media such as blogs, podcasts, social networking sites (SNS) have empowered legitimate use to customers and helped them to search and share information easily; as a result, it significantly affects the behavior of web users (Kucuk \& Krishnamurthy, 2007; Mangold \& Faulds, 2009). Toward to enterprises, social media offers the best personalization to companies by helping them access directly to their target customers (Drury, 2008). Besides, it provides opportunities and convenience to bilateral communication between companies and customers (B2C) or among customers (C2C) (Mangold \& Faulds, 2009). Therefore, in the process of establishing marketing strategy, social media plays an important role as an effective tool that businesses use to communicate to their target customers (Lai \& Li, 2005; Mangold \& Faulds, 2009).

Social networking site (SNS) is the most common form of social media. SNS has been recognized as the main venue for interaction, discussion and communication among people. It is demonstrated by the constantly increasing number of SNS Users worldwide (Lee, Xiong, \& Hu, 2012). Specifically, Facebook, Google Plus, LinkedIn, Twitter respectively attracted about 1.4 billion; 1.1 billion; 347 million; 300 million registered users in 2015. Because of the development and spread of the SNS, enterprises has promoted their brand to the target market through various forms such as banner ads (banner ads, animation, video), classified ads, brand pages (e.g. Facebook fan-pages), advertising events, poll / survey ads (Cuauhtemoc \& Ivonne, 2015). In event-marketing domain, SNS has considered as an important tool in the marketing efforts of companies. In addition, SNS also facilitates positive communication between businesses and customers, as well as stimulating the interaction among customers (Lee et al., 2012).

Facebook has been considered to be the most popular social networking site since it was established in 2004, and this valuable platform is characterized by intensive usage patterns and high interaction (Ellison, Steinfield, \& Lampe, 2007). In fact, Facebook has been serving enormous numbers of users (more than 1.23 billion active 
users) with more than 30 billion pieces of user-generated content (Facebook.com, 2016). Users receive a variety of offers from Facebook such as looking for friends, posting and sharing their profiles, interacting with others by liking and commenting on others' pages, and creating and joining virtual groups. Facebook fan-page has a wide range of functional similarities to an individual's profile page. A Facebook event page has all features of a fan-page and is an official page created as a virtual group by the real public figure, artist, brand, or organization, or by an official representative of the entity. Online users who have common interest such as a local event or a trendy topic are likely to become a member of the virtual group (Lee et al., 2012).

Nowadays, event organizers and planners find it beneficial to use Facebook event pages to increase the number of potential attendees of the event by enabling them to access information on local events and create more social relationships (Becker, Naaman, \& Gravano, 2009). When event organizers announce a promotion or a new event on their Facebook event pages, the online fans (potential attendees) may respond to their information and they can interact directly with other online fans prior to visiting the event. Consequently, many companies now establish Facebook event pages to advertise their special events to potential attendees, establish connections and building relationships with their fans (Lee et al., 2012).

In order to understand consumer-related factors that affect their acceptance of social media (e.g. Facebook) as legitimate marketing tools, previous studies have shown that emotional factors (e.g. surprise, joy, anger..) have significant effect on customer's perception, sharing behavior and intention to accept products (Bigné, Andreu, \& Gnoth, 2005; Dobele, Lindgreen, Beverland, Vanhamme, \& van Wijk, 2007). In other words, if the users have an enjoyable and pleasurable experience related social media, consequently, their attitude toward the product, service or event will be positive. This will result in users can admire, recommend to others, decide to use the product, service, or attend the event. Therefore, when event organizers market their events through Facebook event page, they expect that emotions of online fans will affect intention to visit event of attendees (Lee et al., 2012). Beside the emotional factor, perceived relevance is also an important factor affecting user attitudes towards using social media as it contributes significantly in the success measurement of the information system from user perspective (Shih, 2004). It can be explained that, users perceived that using social media is useful and successful when they could use it to search and gain more information. Regarding to event marketing, via Facebook event pages, online fans feel that their use and become a fan of Facebook event page is useful and convenient if the event organizers provide information which meets their needs.

Hence, this paper aims to synthesize the theoretical basis of the event marketing, technology acceptance model (TAM), emotional factors, perceived relevance factor and its application to Facebook event page, thereby coming out with a conceptual model of the relationships among variables: (1) the emotions that online fans express on Facebook affect their acceptance of the Facebook event page as a legitimate marketing tool; (2) perceived relevance from user perspective influence their acceptance of the Facebook event page; (3) this "acceptance" mechanism has an impact on fans' intentions to attend the event

In order to study on event marketing, this research chose Facebook event page as a study context. This comes from various benefits of Facebook event page: Firstly, most events (e.g. music, culture, sports, tourism) tend to advertise on highly interactive mediums because they make events become more attractive. Facebook is a platform of social networking site that has a wide spread and attracts active users as well as provides more up-to-date information. So, it fulfills the purpose of event marketing (Martensen, Grønholdt, Bendtsen, \& Jensen, 2007). Second, because the event organizers expect to appeal to individuals' emotions and feelings, some event contents (e.g. Facebook event pages) can significantly arouse the user's emotions (Martensen \& Grønholdt, 2008). Furthermore, the social interactions among online fans on Facebook event page are expected to have an emotional bond that leads to raise the number of people visit to event.

\section{Literature Review}

This study applied technology acceptance model (TAM) as a theoretical foundation, then extended the TAM for exploring the roles of online fans' emotions and perceived relevance toward using Facebook event page as well as intention to visit events.

\subsection{Technology Acceptance Model (TAM)}

Davis's technology acceptance model (original TAM) was developed from the theory of reasoned action (TRA) of Fishbein and Ajzen (1975). TRA is a widely used model in studying individual behavior which is determined by behavioral intentions. Individual intention is influenced by two factors: individual attitudes and subjective norms regarding a behavior (Fishbein \& Ajzen, 1975). Specifically, attitudes depict general individual feelings of approval or disapproval toward a specific behavior, subjective norms are considered as influences of the social environment on the individual behavior, and intention describes a person's willingness to perform certain 
behaviors. The expectation-value theory defines attitudes as the way an individual hold strong beliefs and assessments of behavior outcomes. Therefore, the attitude causally links beliefs and behavior in the beliefattitude-intention-behavior relationships. Consequently, Davis proposed TAM for explaining and predicting user acceptance of an information system (IS) (Shih, 2004; Lee et al., 2012; Cuauhtemoc \& Ivonne, 2015).

The TAM is able to explain more than $40 \%$ of users' behavioral intentions to accept new technology (Cuauhtemoc \& Ivonne, 2015; Legris, Ingham, \& Collerette, 2003). The important contribution to develop measurement of the TAM is to identify two important factors belonging to belief: perceived ease of use (PEOU) and perceived usefulness (PU). Davis (1989) defined that perceived usefulness as "the degree to which a person believes that using a particular system would enhance his or her job performance", and perceived ease of use as "the degree to which a person believes that using a particular system would be free of effort". Original TAM has demonstrated that PEOU and PU have a positive effect on user's attitude and their acceptance of technology (Davis, 1989). If we omit other factors, the easier a technology is to use, the more useful it can be. Thus, PEOU has a positive influence on PU (Venkatesh, 2000).

While the original TAM focuses on explaining about the acceptance of technology in workplaces, several previous studies also applied the TAM to explain about online user's behavior in multiple situations such as website use (Moon \& Kim 2001; Porter \& Donthu 2006), online shopping (Childers, Carr, Peck, \& Carson, 2001; Koufaris, 2002; Pavlou, 2003), online banking acceptance (Wang, Wang, Lin, \& Tang, 2003; Pikkarainen, Pikkarainen, \& Pahnila, 2004), e-learning (Cheung, \& Vogel, 2013). In particular, previous research also suggested that the TAM model is used to explain behavior based on the use of social networking sites (Lee et al., 2012; Cuauhtemoc \& Ivonne, 2015; Ainin, Naqshbandi, Moghavvemi, \& Jaafar, 2015).

\subsection{Extended Technology Acceptance Model (Extended TAM)}

In the process of applying the original TAM, this study found that the original TAM will not fully explain the potential significant factors which affect user's acceptance of the Facebook event page. Thus, this research extended the TAM to provide a more completed explanation.

Based on the analysis of the relationships among research concepts in the extended TAM from previous studies (King \& He, 2006; Moon \& Kim, 2001; Wu \& Li, 2007; Lee et al. 2012), the study expanded the original TAM by adding three factors:

The first factor is emotion: Bigne et al. (2005) revealed that emotion is considered as an important prerequisite factor in decision-making processes based on the Theory of Planned Behavior by Ajzen(1991). Besides, emotional stimulation in the behavioral models can provide knowledge to influence customer behaviors (Lee et al., 2012). In addition, valence (positive and negative emotions) influences perceived enjoyment, perceived ease of use and perceived usefulness (Wu \& $\mathrm{Li}$, 2007). Therefore, this study added emotion as prior factor following the research model of King and He (2006) and also having the same perspective with study of Lee et al. (2012). Two components of emotional factors are arousal and valence. Arousal refers to a continuum that varies from calm to excitement (change in intensity), whereas Valence refers to a continuum that varies from positive to negative with neutral in the middle (Dolcos et al., 2004; Lang et al., 1993; Russell, 1980). (Dolcos, LaBara, \& Cabezaa, 2004; Lang, Greenwald, Bradley, \& Hamm, 1993; Russell, 1980).

The second factor is Perceived enjoyment: Perceived enjoyment is considered as a factor suggested from other theories in the research model of King and He (2006) and as intrinsic motivation following the model of Wu and $\mathrm{Li}$ (2007). The intrinsic motivation is recognized as the important antecedent factor affecting users' attitude and behaviors (Davis, Bagozzi, \& Warshaw, 1992; Wu \& Li, 2007; Zhang, Zhao, \& Tan, 2008). According to Venkatesh (2000), intrinsic motivation includes two components: perceived playfulness and perceived enjoyment, in which "perceived playfulness refers general beliefs about computers and computer usage, and perceived enjoyment indicates beliefs that are shaped based on direct experiences with the target system". Perceived playfulness is predicted to decrease over time when users' experiences raise, thereby, perceived enjoyment toward a particular system will be more dominant influence (Lee et al., 2012). Also, the higher the level of perceived ease of use is, the higher perceived enjoyment is supposed to be (Venkatesh, 2000). In the context study of Facebook event page, if users used more this application, their experiences get richer, thus, Lee et al. (2012) suggested that perceived playfulness is ultimately affected by perceived enjoyment. The study, therefore, only added perceived enjoyment factor into the TAM following the research model of Lee et al. (2012).

The third factor is Perceived relevance: DeLone and Mclean (1992) concluded that information quality is important element in measuring the success of information system (IS) from user's perspective. "Information quality was defined as the output quality of an IS and was operationalized as a multi-attribute construct relating to information characteristics" (Shih, 2004). Many previous studies have used perceived relevance to measure 
information quality (Ahituv, 1980; Bailey \& Pearson, 1983; Miller \& Doyle, 1987; Srinivasan, 1985; Shih, 2004). Perceived relevance was defined as "an estimate of appropriateness existing between information provided and information used as judged by a person" (Saracevic, 1970, pp, 111-151.). Schamber et al. (1990) indicated that perceived relevance is related to user cognition of the gap between information acquired and information requirements at a specific point of time. In other words, perceived relevance refers to usefulness, utility (including ease of use), attitudes of judges and satisfaction. From a user perspective, perceived relevance is evaluated subjectively base on user's information needs at work which could vary with their environment (Park, 1994). In regard to event marketing, if online fans perceive Facebook event pages meet their information needs, they feel that their use and becoming a fan of Facebook event page is useful and convenient. Thus, this research added perceived relevance into the TAM. It is considered as a factor suggested from other theories in the research model of King and He (2006) and factor of information need context in the model of Shih (2004).

\subsection{Relationships among Research Concepts}

There are different approaches about the relationship between arousal and valence (Shapiro, MacInnis, \& Park, 2002). On the one hand, some researchers (e.g. Aylesworth \& MacKenzie, 1998) argue that these two factors interact in a causal mechanism in which the higher arousal leads to highly increasing valence. On the other hand, MacInnis and Jaworski (1989) argue that arousal is likely to distract individuals' attention from dealing with subsequent information, which means that it separates to valence. Lee et al. (2012) believed that users hardly express extreme arousal on social network sites, so authors concurred with the argument that arousal is the determinant of valence. In addition, findings from study by Lee et al. (2012) demonstrated that arousal of Facebook user has positive effect on their valence. Based on arguments, the first hypothesis was established:

H1: On the Facebook event page, arousal has positive impact on valence

Findings from previous studies have demonstrated that valence has significant direct effect on perceived usefulness, perceived ease of use (e.g. Saadé \& Kira, 2006; Venkatesh, 2000; Lee et al., 2012; Wu \& Li, 2007), and perceived enjoyment (Lee et al., 2012; Wu \& Li, 2007). It can be explained that, users express positive emotion (e.g. happiness and pleasure) toward a new technology when they feel that it takes a little efforts to acquire their purpose by using this technology (Briggs, Reinig, \& de Vreede, 2008; Beaudry \& Pinsonneault, 2010). With regard to event marketing, Facebook event pages will not require online fans with a lot effort but they still gain easily the information about the events and interact highly with others who have "common interests". Thus, it leads Facebook users' attitudes toward Facebook event page to be positive (Lee et al., 2013). Furthermore, empirical studies (e.g. Lee et al., 2013; Sas, Dix, Hart, \& Su, 2009) indicated that in Facebook users' mind, Facebook brings unforgettable experiences to online fans such as: valence, usefulness and enjoyment. Thus, three following hypotheses were established:

H2: On the Facebook event page, valence has positive impact on perceived usefulness

H3: On the Facebook event page, valence has positive impact on perceived ease of use

H4: On the Facebook event page, valence has positive impact on perceived enjoyment

The strong influence of perceived ease of use on perceived usefulness was revealed in the original TAM (Davis, 1989). The empirical results from studies (e.g. Moon \& Kim, 2001; Lee et al., 2012; Cuauhtemoc \& Ivonne, 2015; Shih, 2004; Cheung \& Vogel, 2013) also confirmed this relationship. In addition, perceived ease of use has positive effect on perceived enjoyment in case of Facebook event page (Lee et al., 2012; Venkatesh, 2004). User's acceptance of a new technology is strongly influenced by perceived ease of use (Davis, 1989; Davis et al., 1989). If users feel this technology which is easier to use than others, they almost accept this technology. Therefore, complexity of the technology is higher, the acceptance rate is lower (Selamat, Jaffar, \& Ong, 2009). In study context as online (e.g. social media), perceived ease of use is considered as an attitude predictor toward using social media (e.g. Facebook) (Lee et al., 2012, Moon \& Kim, 2001; Stern \& Taylor, 2007). From that, the study proposed three following hypotheses:

H5: On the Facebook event page, perceived ease of use has positive impact on perceived usefulness

H6: On the Facebook event page, perceived ease of use has positive impact on perceived enjoyment

H7: On the Facebook event page, perceived ease of use has positive impact on users' attitude

Social networking site (SNS) is recognized as a web-based platform that provides the users with a variety of benefits including hedonic (e.g. enjoyment, pleasure, entertainment) and utilitarian (e.g. communication, information acquisition, socialization, information exchange, advertising) (Cuauhtemoc \& Ivonne, 2015). The relationship between utilitarianism and perceived usefulness contributes to the creation of positive attitudes 
toward technologies (Cuauhtemoc \& Ivonne, 2015). Users have positive attitudes toward the technology when users feel that they have useful experience of the technology and they believe that this technology helps them acquire the information needed for their decision-making process and achieve important objectives in their lives (Calder, Malthouse, \& Schaedel, 2009). Besides, the relationship between perceived usefulness and attitudes toward the technology is also confirmed by previous studies (e.g. Moon \& Kim, 2001; Cuauhtemoc \& Ivonne, 2015; Shih, 2004; Cheung \& Vogel, 2013). Thus, the following hypothesis was proposed:

H8: On the Facebook event page, perceived usefulness has positive impact on users' attitude

Results of empirical studies confirmed that perceived enjoyment has positive impact on users' attitude toward knowledge management program (Wu \& Li, 2007) or the Facebook event page (Lee et al., 2012). Therefore, the following hypothesis was established:

H9: On the Facebook event page, perceived enjoyment has positive impact on users' attitude

Information quality determines the success of website design (Liu \& Arnett, 2000) and relates to individual performance of non-work activities on the WWW (D'Ambra \& Rice, 2001). Perceived relevance is capable of measuring of information system output or success (Froehlich, 1994; Gefen \& Keil, 1998). In addition, results of study by Shih (2004) confirmed that perceived relevance has positive influence on technology (perceived ease of use and perceived usefulness) and users' attitudes toward using Internet at information seeking stage. Based on evidences from previous studies, the study established three following hypotheses:

H10: On the Facebook event page, perceived relevance has positive impact on perceived usefulness

H11: On the Facebook event page, perceived relevance has positive impact on perceived ease of use

H12: On the Facebook event page, perceived relevance has positive impact on users' attitude

Individual intention is affected by two factors: attitude and subjective norms (Davis, 1989; Cheung \& Vogel, 2013). According to findings of study by Lee et al. (2012), users' attitude towards the Facebook event page has a powerful influence on their intention to visit events. Thus, the following hypothesis was established:

H13: On the Facebook event page, users' attitude on Facebook event page has positive impact on users' intention to attend event

As a result, a new adapted model has been proposed based on the literature review collection of previous studies. In terms of discussed issue, eight constructs were selected to represent the relationships among research concepts. The conceptual framework of this research is shown in Figure 1.

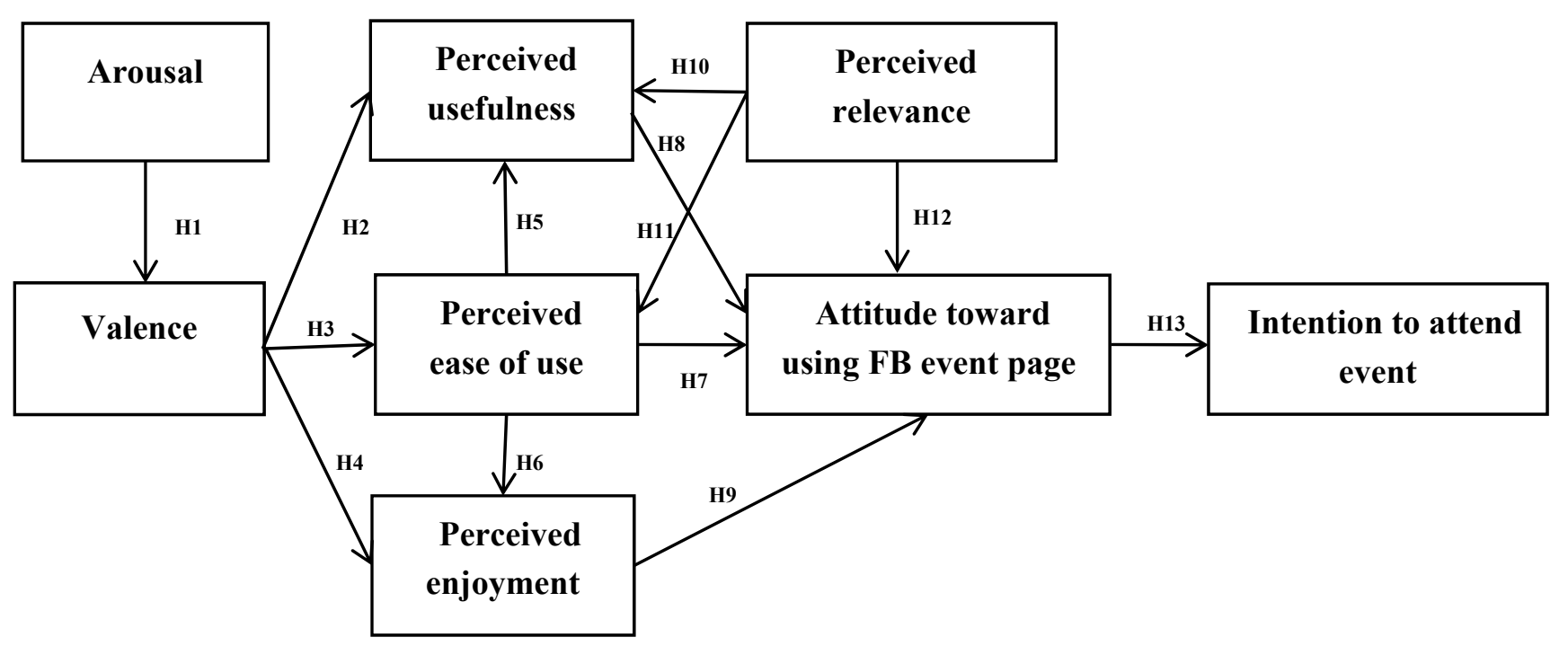

Figure 1. Conceptual framework

\section{Conclusion}

It can be said that the impact of social media on user's behaviors has been one of the interesting topics in multiple context. In event-marketing domain, the most popular SNS- Facebook has considered as an important 
tool in the marketing efforts of companies. Therefore, many companies now create Facebook event pages in order to advertise their special events to potential attendees. However, the important issue of event organizers in establishing and operating their official Face book event page is how to explain factors related users make them to join virtual groups and consider Facebook event page as a legitimate marketing tool, thus it impacts to their decision whether or not to go to visit events. In order to explain the inner-mechanism through which online fans accept Facebook event page as legitimate marketing channel and impacts fans' intentions to attend the event, this work applied TAM developed by Davis (1989) as a theoretical foundation. This is because TAM focuses on predicting and explaining human behavior to use a new technology. In the process of applying the original TAM, this study found that original TAM will not fully explain the potential significant factors which affect user's acceptance of Facebook event pages. The reason comes from TAM only identifies two factors belonging to belief: perceived ease of use (PEOU) and perceived usefulness (PU) which have a positive effect on user's attitude and their acceptance of technology. Besides these two factors, other important factors also significant impact user's attitude toward using Facebook event page.

Based on synthesize literature review from previous studies and analyzed the study context (Facebook event page), this study extended the TAM via adding four factors: emotion (arousal, valence); perceived enjoyment; perceived relevance and proposed 13 hypotheses to demonstrate relationships among research concepts. This study aims to contribute to the literature in event marketing domain and help event organizers to find suitable model to survey their online fans.

This study only stops to propose the research framework between variable concepts, so the paper suggests some directions for future research: (1) continuing to build measuring items for research concepts and conducting testing to establish scales for each specific Facebook event page; (2) continuing to test the proposed hypothetical model for a specific Facebook event page, and then compare the result with the results of previous researches and the theory.

\section{References}

Ajzen, I. (1991). The theory of planned behavior. Organizational Behavior and Human Decision Processes, 50(2), 179-211. https://doi.org/10.1016/0749-5978(91)90020-T

Ahituv, N. (1980). A systematic approach toward assessing the value of an information system. MIS Quarterly, 4(4), 61-75. https://doi.org/10.2307/248961

Ainin, S., Naqshbandi, M. M., Moghavvemi, S., \& Jaafar, N. I. (2015). Facebook usage, socialization and academic performance. Computers \& Education, 83, 64-73. https://doi.org/10.1016/j.compedu.2014.12.018

Aylesworth, A. B., \& MacKenzie, S. B. (1998). Context is key: the effect of program induced mood on thoughts about the ad. Journal of Advertising, 27(2), 17-31. https://doi.org/10.1080/00913367.1998.10673550

Bailey, J. E., \& Pearson, S. W. (1983). Development of a tool for measuring and analyzing computer user satisfaction. Management Science, 29(6), 530-545. https://doi.org/10.1287/mnsc.29.5.530

Becker, H., Naaman, M., \& Gravano, L. (2009). Event identification in social media. In: Twelfth International Workshop on the Web and Databases (WebDB 2009), Providence, Rhode Island, USA. http://webdb09.cse.buffalo.edu/papers/Paper36/webdb09-final.pdf

Beaudry, A., Pinsonneault, A. (2005). Understanding user responses to information technology: a coping model of user adaption. MIS Quarterly, 29(3), 493-524. https://doi.org/10.2307/25148693

Bigné, J. E., Andreu, L., \& Gnoth, J. (2005). The theme park experience: an analysis of pleasure, arousal and satisfaction. Tourism Management, 26(6), 833-844. https://doi.org/10.1016/j.tourman.2004.05.006

Briggs, R. O., Reinig, B. A., de Vreede, G-J. (2008). The yield shift theory of satisfaction and its application to the IS/IT domain. Journal of the Association for Information Systems, 9(5), 267-293.

Calder, B. J., Malthouse, E. C., \& Schaedel, U. (2009). An experimental study of the relationship between online engagement and advertising effectiveness. Journal of Interactive Marketing, 23(4), 321-331. https://doi.org/0.1016/j.intmar.2009.07.002

Cheung, R., \& Vogel, D. (2013). Predicting user acceptance of collaborative technologies: An extension of the technology acceptance model for e-learning. Computers \& Education, 63, 160-175. https://doi.org/10.1016/j.compedu.2012.12.003

Childers, T. L., Carr, C. L., Peck, J., \& Carson, S. (2002). Hedonic and utilitarian motivations for online retail shopping behavior. Journal of Retailing, 77(4), 511-535. https://doi.org/10.1016/S0022-4359(01)00056-2 
Cuauhtemoc, L-N., \& Ivonne, M. T. (2015). Consumer attitudes toward social network advertising. Journal of Current Issues \& Research in Advertising, 36(1), 1-19. https://doi.org/10.1080/10641734.2014.912595

D'Ambra, J., \& Rice, R. E. (2001). Emerging factors in user evaluation of the World Wide Web. Information and Management, 38(6), 373-384. https://doi.org/10.1016/S0378-7206(00)00077-X

Davis, F. D. (1989). Perceived usefullness, perceived ease of use, and user acceptance of information tehcnology. MIS Quarterly, 13(3), 319-339. https://doi.org/10.2307/249008

Davis, F. D., Bagozzi, R. P., \& Warshaw, P. R. (1989). A comparison of two theoretical models. Management Science, 35(8), 982-1003. https://doi.org/10.1287/mnsc.35.8.982

Davis, F. D., Bagozzi, R. P., \& Warshaw, P. R. (1992). Extrinsic and intrinsic motivation to use computers in the workplace. Journal of Applied Social Psychology, 22(14), 1111-1132. https://doi.org/10.1111/j.1559-1816.1992.tb00945.x

DeLone, W. H., \& McLean, E. R. (1992). Information systems success: the quest for the dependent variable. Information Systems Research, 3(4), 60-95. https://doi.org/10.1287/isre.3.1.60

Dobele, A., Lindgreen, A., Beverland, M., Vanhamme, J., \& van Wijk, R. (2007). Why pass on viral messages? Because they connect emotionally. Business Horizons, 50(4), 291-304. https://doi.org/10.1016/j.bushor.2007.01.004

Dolcos, F., LaBara, K. S., \& Cabezaa, R. (2004). Dissociable effects of arousal and valence on prefrontal activity indexing emotional evaluation and subsequent memory: an event related fMRI study. NeuroImage, 23(1), 64-74. https://doi.org/10.1016/j.neuroimage.2004.05.015

Drury, G. (2008). Social media: should marketers engage and how can it be done effectively. Journal of Direct, Data and Digital Marketing Practice, 9(3), 274-277. https://doi.org/10.1057/palgrave.dddmp.4350096

Ellison, N. B., Steinfield, C., \& Lampe, C. (2007). The benefits of Facebook friends: social capital and college students' use of online social network sites. Journal of Computer Mediated Communication, 12(4), 1143-1168. https://doi.org/10.1111/j.1083-6101.2007.00367.x

Facebook.com. (2016). Facebook Press Room Statistics. Retrieved from https://newsroom.fb.com/company-info/

Fishbein, M., \& Ajzen, I. (1975). Belief, Attitude, Intention and Behavior: An introduction to theory and research. Addison-Wesley, Reading, MA.

Froehlich, T. J. (1994). Relevance reconsidered: towards an agenda for the 21 st century. Journal of the American $\begin{array}{lllll}\text { Society for Information } & \text { Science, } & \text { 45(3), }\end{array}$ https://doi.org/10.1002/(SICI)1097-4571(199404)45:3<124::AID-ASI2>3.0.CO;2-8

Gefen, D., \& Keil, M. (1998). The impact of developer responsiveness on perceptions of usefulness and ease of use: an extension of the technology acceptance model. Data Base, 29(2), 35-49. https://doi.org/10.1145/298752.298757

King, W. R., \& He, J. (2006). A meta-analysis of the technology acceptance model. Information and Management, 43(6), 740-755. https://doi.org/10.1016/j.im.2006.05.003

Koufaris, M. (2002). Applying the technology acceptance model and flow theory to online consumer behavior. Information Systems Research, 13(2), 205-223. https://doi.org/10.1287/isre.13.2.205.83

Kucuk, S. U., \& Krishnamurthy, S. (2007). An analysis of consumer power on the Internet. Technovation, 27(1), 47-56. https://doi.org/10.1016/j.technovation.2006.05.002

Lai, V. S., \& Li, H. (2005). Technology acceptance model for Internet banking: an invariance analysis. Information and Management, 42(2), 373-386. https://doi.org/ 10.1016/j.im.2004.01.007

Lang, P. J., Greenwald, M. K., Bradley, M. M., \& Hamm, A. O. (1993). Looking at pictures: affective, facial, visceral and behavioral reactions. Psychophysiology, 30(3), 261-273. https://doi.org/10.1111/j.1469-8986.1993.tb03352.x

Lee, W., Xiong, L., \& Hu, C. (2012). The effect of Facebook users'arousal and valence on intention to go to festival: Applying an extension of the technology acceptance model. International journal of Hospitality management, 31(3), 819-827. https://doi.org/10.1016/j.jjhm.2011.09.018

Legris, P., Ingham, J., \& Collerette, P. (2003). Why do people use information technology? A critical review of the technology acceptance model. Information \& Management, 40(3), 191-204. https://doi.org/10.1016/S0378-7206(01)00143-4 
Liu, C., \& Arnett, K. P. (2000). Exploring the factors associated with website success in the context of electronic commerce. Information and Management, 38(1), 23-33. https://doi.org/10.1016/S0378-7206(00)00049-5

MacInnis, D. J., \& Jaworski, B. J. (1989). Information processing from advertisements: toward an integrative framework. Journal of Marketing, 53(4), 1-23. https://doi.org/10.2307/1251376

Mangold, W. G., \& Faulds, D. J. (2009). Social media: the new hybrid element of the promotion mix. Business Horizons, 52(4), 357-365. https://doi.org/10.1016/j.bushor.2009.03.002

Martensen, A., \& Grønholdt, L. (2008). How events work: understanding consumer responses to event marketing. Innovative Marketing, 4(4), 45-57.

Martensen, A., Grønholdt, L., Bendtsen, L., \& Jensen, M. J. (2007). Application of a model for the effectiveness of event marketing. Journal of Advertising Research, 47(3), 283-301. https://doi.org/10.2501/S0021849907070316

Miller, J., \& Doyle, B. A. (1987). Measuring effectiveness of computer based information systems in the financial services sector. MIS Quarterly, 11(1), 107-124. https://doi.org/10.2307/248832

Moon, J. W., \& Kim, Y. G. (2001). Extending the TAM for a world-wide-web context. Information \& Management, 38(4), 217-230. https://doi.org/10.1016/S0378-7206(00)00061-6

Park, T. K. (1994). Toward a theory of user-based relevance: a call for a new paradigm of inquiry. Journal of the American Society for Information Science, 45(3), 135-141. https://doi.org/10.1002/(SICI)1097-4571(199404)45:3<135::AID-ASI3>3.0.CO;2-1

Pavlou, P. A. (2003). Consumer acceptance of electronic commerce: Integrating trust and risk with the technology acceptance model. International Journal of Electronic Commerce, 7(3), 101-134. https://doi.org/10.1080/10864415.2003.11044275

Pikkarainen, T., K., Pikkarainen, H. K., \& Pahnila, S. (2004). Consumer acceptance of online banking: An extension of the technology acceptance model. Internet Research, 14(3), 224-235. https://doi.org/10.1108/10662240410542652

Porter, C. E., \& Donthu, N. (2006). Using the technology acceptance model to explain how attitudes determine Internet usage: The role of perceived access barriers and demographics. Journal of Business Research, 59(9), 999-1007. https://doi.org/10.1016/j.jbusres.2006.06.003

Russell, J. A. (1980). A circumplex model of affect. Journal of Personality and Social Psychology, 39(6), 11611178. https://doi.org/10.1037/h0077714

Saadé, R. G., \& Kira, D. (2006). The emotional state of technology acceptance. Issues in Informing Science and Information Technology, 3, 529-540.

Saracevic, T. (1970). The concept of "relevance" in information science: a historical review. In T. Saracevic (Ed.), Introduction to Information Science. R.R. Bowker, New York.

Sas, C., Dix, A., Hart, J., \& Su, R. (2009). Emotional experiences on Facebook site. In: Proceedings of the 27th International Conference Extended Abstracts on Human Factors in Computer Systems, Association for Computing Machinery, Boston, MA/New York, NY, 4345-4350. https://doi.org/10.1145/1520340.1520664

Schamber, L., Eisenberg, M., \& Nilan, M. (1990). A re-examination of relevance: toward a dynamic, situational definition. Information Processing and Management, 26(6), 755-776. https://doi.org/10.1016/0306-4573(90)90050-C

Selamat, Z., Jaffar, N., \& Ong., B. H. (2009). Technology acceptance in Malaysian banking industry. European Journal of Economics, Finance and Administrative Sciences, 1(17), 143-155.

Shapiro, S., MacInnis, D. J., \& Park, C. W. (2002). Understanding program-induced mood effects: decoupling arousal from valence. Journal of Advertising, 31(4), 15-26. https://doi.org/10.1080/00913367.2002.10673682

Shih, H. P. (2004). Extended technology acceptance model of Internet utilization behavior. Information and Management, 4l(6), 719-729. https://doi.org/10.1016/j.im.2003.08.009

Srinivasan, A. (1985). Alternative measures of system effectiveness: associations and implications. MIS Quarterly, 9(3), 243-253. https://doi.org/10.2307/248951

Stern, L. A., \& Taylor, K. (2007). Social networking on Facebook. Journal of the Communication, Speech \& Theatre Association of North Dakota, 20, 9-20. 
Venkatesh,V. (2000). Determinants of perceived ease of use: integrating control, intrinsic motivation, and emotion into the technology acceptance model. Information Systems Research, 11(4), 342-365. https://doi.org/10.1287/isre.11.4.342.11872

Wang, Y. S., Wang, Y. M., Lin, H. H., \& Tang, T. I. (2003). Determinants of user acceptance of internet banking: An empirical study. International Journal of Service Industry Management, 14(5), 501-519. https://doi.org/10.1108/09564230310500192

Wu, W-Y., \& Li, C.-Y. (2007). A contingency approach to incorporate human, emotional and social influence into a TAM for KM programs. Journal of Information Science, 33(3), $275-297$. https://doi.org/10.1177/0165551506070730

Zhang, S., Zhao, J., \& Tan, W. (2008). Extending TAM for online learning systems: an intrinsic motivation $\begin{array}{lllll}\text { perspective. Tsinghua Science } & \text { Technology, }\end{array}$ https://doi.org/10.1016/S1007-0214(08)70050-6

\section{Copyrights}

Copyright for this article is retained by the author(s), with first publication rights granted to the journal.

This is an open-access article distributed under the terms and conditions of the Creative Commons Attribution license (http://creativecommons.org/licenses/by/4.0/). 